\title{
最近の鍛造用皮膜・潤滑剤の評価方法について
}

五十川幸宏 $* 1$, 伊藤樹一 $* 2$

\section{Recent Evaluation Method for Forging Luburicants}

\author{
Sachihiro Isogawa and Shigekazu Ito
}

\section{Synopsis}

The forging has the following features compared with other metal working methods.

1. The surface expansion ratio at the forging is extremely large.

2. The normal pressure at the forging is extremely large.

3. The supply of the lubricant at the forging is difficult.

The tribo-simulator for the forging that can take out only the friction energy that shows the feature between the tool and the work of the forging process described now is desired.

In this explanation, the behavior of the surface expansion ratio and the normal pressure change in a basic deformation behavior at the forging is summarized. The feature of the tribo-simulator for the forging that has been proposed so far and the result achieved by it are shown, and the way it should be of the tribo-simulator in the future is described.

\section{1.まえがき}

鍛造加工の分野では, 原価低減のための生産速度の向上 に加えて, ネットシェイプ化による後加工工程の省略, 従 来では不可能であった難加工材に対する鍛造技術の確立 などがこれまでにも増して必要とされている。これらを達 成するために, 被加工材料の改良開発, 工程設計技術の高 度化, 加工工具の高寿命化などに対する研究が積極的に行 われている。これらと平行して高性能な被膜・潤滑剂の開 発は, 摩擦の低減による鍛造荷重の軽減や型寿命の向上に よる量産技術の確立のために必要不可欠である.

新しい被膜・潤滑剤の開発に際して，その特性を評価す るための汎用の基礎的摩擦試験 1) としてバウデン試験法 がある。しかし，接触面圧が実加工時と比較して低く，大 きな塑性流動を伴わないために鍛造時の挙動を見積るこ とは困難である。鍛造用被膜・潤滑剤の評価方法としては リング圧縮法 ${ }^{2)}$ が広く用いられている。本手法は，摩擦 係数が絶対值として求まるため, 極めて有用な手法である が, 据込みに準じた変形様式のため表面積の拡大比が高々
3 倍程度であり, 後方押出しのような実際の加工にて生ず る表面積拡大比が 5 〜 40 の場合 ${ }^{3)}$ と比較すると小さく, 塑性流動が大きい場合の被膜・潤滑特性の適用限界を求め るには問題がある。その他, 圧縮回転法, くさび引っかき 法などの種々の試験法 4) が提案されているが, 塑性流動 が比較的少なく，かつ特殊な試験装置を必要とするため, 広く利用される状況にはない.

一方, 従来より被膜 ・潤滑剂の開発メーカは, 基礎試験 により評価し，最適と思われる製品をユーザに提案し， ユーザでの実機テストを受けてきた.ユーザでの実機テス トを行うに当たっては,多大なリスクを犯して実生産を休 止して実験のためだけの稼働を行う. 数千から数万個の量 産レベルまで試作を行い, 製品に対する焼付き程度の差異 や, 金型の摩耗・損傷の程度を数種の被膜・潤滑剂につい て調べるため多くの時間と経費を費やしている.これらを 避けるために, 開発メーカ自らが生産設備を導入したり, 研究機関のプレスを借用して, 実生産に近い状態まで連続 鍛造を行い, それによって被膜・潤滑剂の評価を行う場合 もある。 
このような現状において，現実的な塑性変形（高い面圧 と大きな塑性流動）を良く模擬できる被膜・潤滑剤の評価 試験方法の確立は, 被膜・潤滑剤の開発メーカのみならず ユーザにとって強く期待されている. 本解説では, これま での鍛造用被膜・潤滑剂の評価試験方法を概括して，将来 のトライボ評価試験法のあるべき姿を探りたい.

\section{2. 実加工時の変形挙動}

鍛造加工される部品の形状は, その機能および特性によ り種々である。しかし，鍛造加工における部品の成形工程 は，(1) 据込み，(2) 前方押出し，(3) 後方押出しの 3 つの 基本的な変形様式の単独あるいはそれらの組合せからな る. 実変形においては, 上記の基本 3 変形様式が単独ある

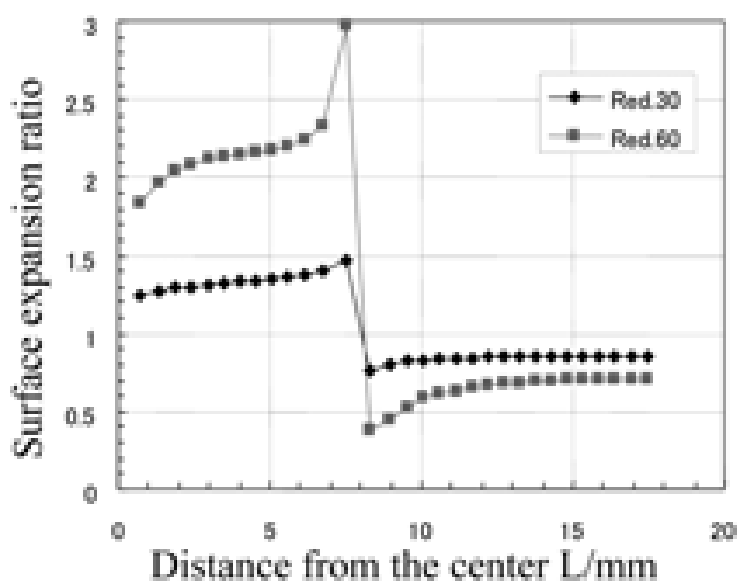

(a) Surface expansion ratio at contact surface and lateral surface

Fig.1. Surface expansion ratio in Upsetting.

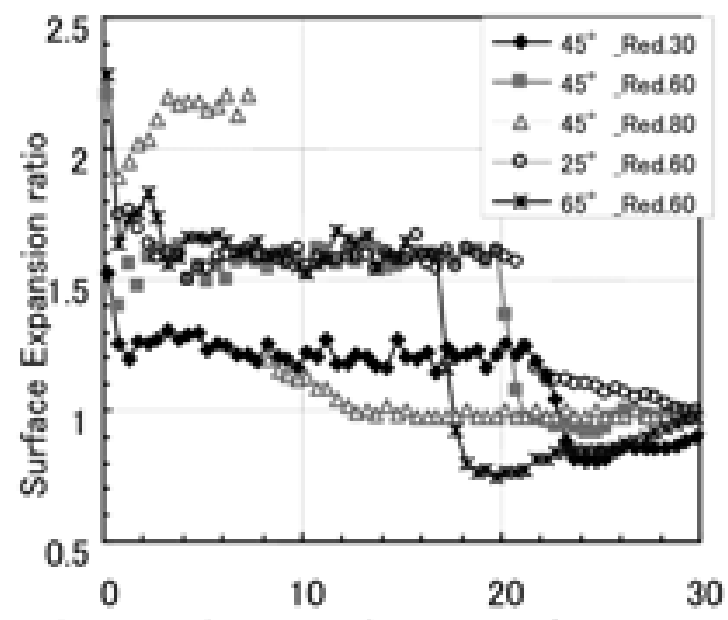

Distance from top of specimen /mm

(a) Surface expansion ratio after forward extrusion
いは同時に生じながら変形が進む.したがって, 多くの場 合に実部品の変形を基本3形式に分解してトライボ特性を 評価することにより，被膜・潤滑に関わる特性の実加工へ の適用限界を評価できると考える。

Fig.1は，円柱状試験片を据込んだ時の金型と接触する 面の表面積拡大比を示した。据込み時の最大の問題は, 試 験片端面と側面をつなぐエッジ部のまくれ込み現象（フォー ルディング）の問題である．上・下の平ダイスで圧縮変形 させているので, メタルフローは半径方向に生じ, 特に側 面の拘束がなければ，焼付きで生産がとまることはない. しかし, 側面が直角にメタルフローの方向を曲げられてダ イス面に接触し圧縮加工を受けるので, 極めて大きな面圧 とひずみが発生する。

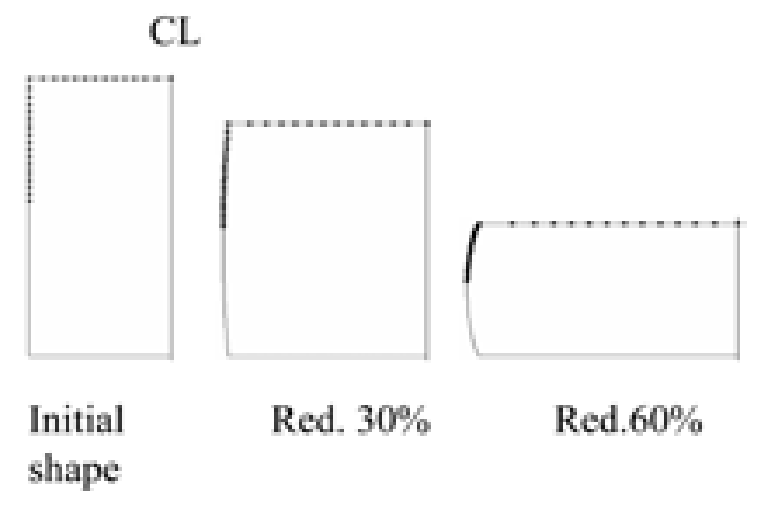

(b) Deformed shape $(\mathrm{m}=0.1)$

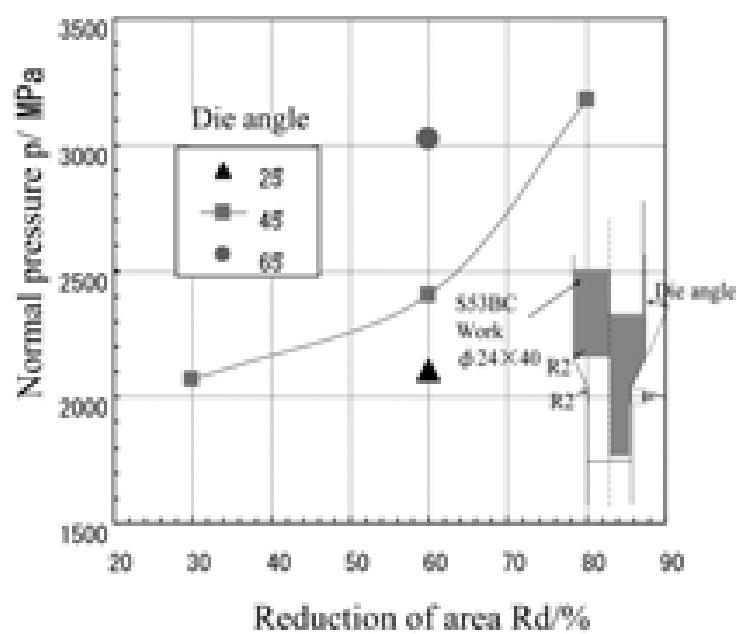

(b) Normal pressure depend on reduction of area

Fig.2. Surface expansion ratio and normal pressure in Forward Extrusion. 
Fig.2 は, 円柱状試験片を前方押出しした時の，変形前 の素材先端端面からの表面積拡大比とそのときの面圧を 示したものである. Fig.2-(a)でわかるように, 表面積拡大 比は, 高々 2.5 程度である。通常ならば，表面積拡大比が 40 程度まで追随するリン酸亜鉛被膜を使用するほどの困 難な成形ではない。一般に油潤滑で加工が可能である。し かし, Fig.2-(b) に示すように，ダイス角と減面率に依存し て接触面圧は大きく変化するので, 圧力に対する被膜・潤 滑剂の性能が重要である。

据込み一押出しのような連続加工の場合には, 据込み面 の局部ひずみが次工程の押出しで大きく拡大されるため, 初期の被膜の厚みが確保されない場合, 焼付き発生の原因 となる。また，押出し部材の先端にエッジ部があると被膜 の密着効果が低下するのでこれもまた焼付きの原因とな る.

Fig.3 は, 円柱状試験片の後方押出し時の変形挙動を, 内表面の各位置に対して面圧と表面積拡大比 5) で示した. 後方押出し時に使用されるパンチ先端 R 2.5 , ランド長さ 2 $\mathrm{mm}$ で押出した時の内表面の表面積拡大の状況を Fig.3-(a) に示した. Fig.3-(b) に示すように，パンチコーナ R2.5 の 部位から急激に拡大され, またメタルフローは一瞬にして 直角に近い角度で曲げられるため, 被膜の追随性は極めて 高い状態が要求される.パンチとの接触面のメタルフロー は，図中の A-B 間，すなわちパンチの $\mathrm{R}$ 部で拡大される ため変形は極めて不安定であり, 被膜の密着性と追随性も 含めた潤滑状態のバラッキが成形挙動に大きく影響を及 ぼすと考えられる。
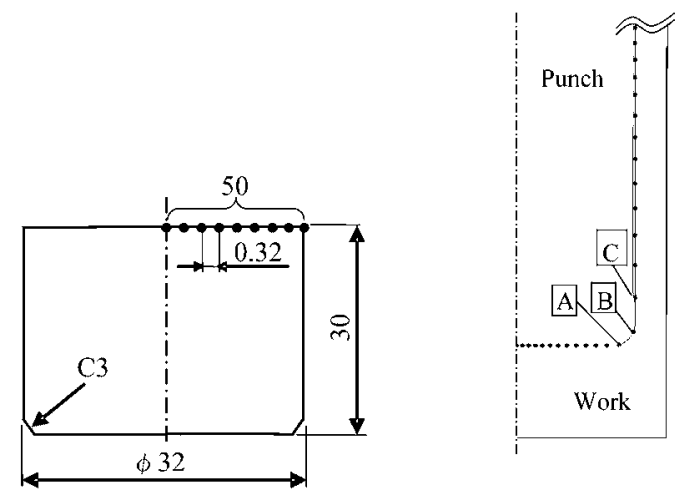

(a) Schematic illustration of work piece before and after deformation
実際の加工は, 上記に示した $3 つ の$ 基本変形様式の組合 せであるので,トライボ特性も基本変形の場合に生ずる問 題をうまく区別することにより評価が可能であると考え る.

\section{3. トライボ特性評価法および試験機}

鍛造加工におけるトライボ特性評価の目的の一つは, 実 加工における工具と被加工材境界面の接触状態を実験室 的な規模で模擬することである.すなわち摩擦係数や金型 の摩耗量, 被加工材と工具との焼付き限界などのトライボ 特性值を定量的に計測し, トライボ性能の評価やその機構 の解明を行うことである. その観点から, トライボシミュ レータは素材と工具間の摩擦抵抗を直接計測できること が好ましい.

Table 16)に塑性加工における各種摩擦条件を示した. 鍛 造加工は, 面圧, 摩擦界面温度, 表面積拡大比のどれを とっても他の塑性加工と比べて厳しい苛酷な加工である. とくに鍛造加工を困難にしている点は, 加工中に外部から の潤滑剂の供給が困難な状態で工具面圧が高く表面積拡 大比が大きいことであり,この 2 つの条件因子は鍛造加工 のトライボ特性評価值として最低限具備すべき条件と考 えられる。

Fig.47) は，鍛造加工で製造される製品の一部について， トライボ特性の評価パラメータとして, 面圧と表面積拡大 比を取り上げ，その範囲を示したものである．歯車類は， 塑性変形に伴う素材表面の拡大よりも加工時の工具面圧 がその成形を困難なものにしており, 被膜の耐圧性が重要

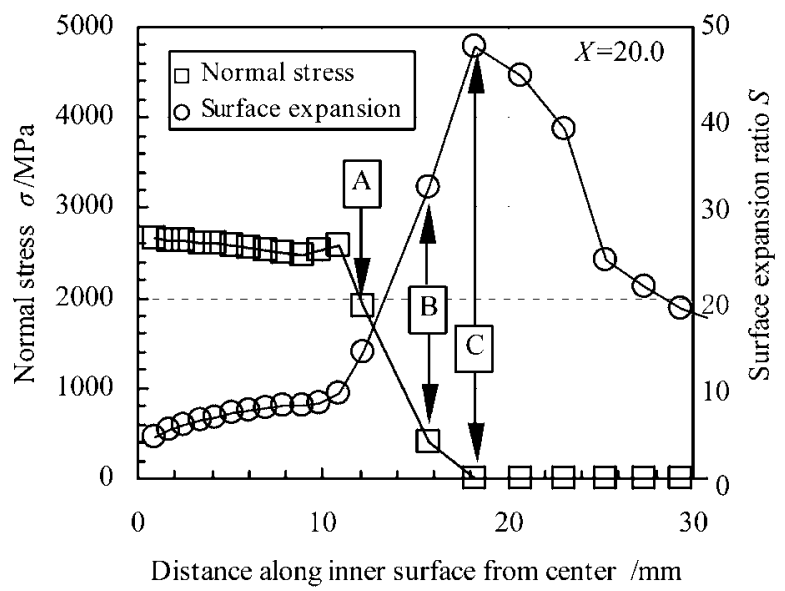

(b) Distribution of surface expansion ratio

Fig.3. Relationship between normal pressure and surface expansion ratio in backward extrusion. 


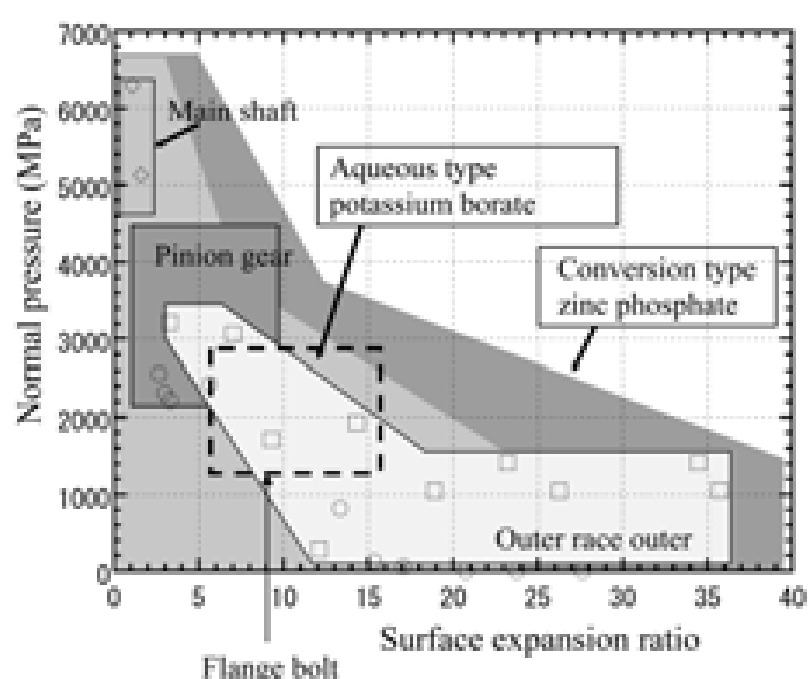

Fig.4. Lubricating condition for forging components by numerical simulation.
である.一方, 等速ジョイントなどに関しては, カップの 部分は極めて大きな表面積の拡大を受けているので, 加工 時においては被膜の追随性が大きな指標となる。このよう に，製品ごとに成形時の重要なトライボ因子は異なる.

Table 2 と Fig.5 ～Fig.15 にこれまでに提案された試験 方法の中から実際に実用試験として用いられている評価 試験方法をまとめた。リング圧縮試験は，塑性流動が大き い場合に対しての適用には問題があるが, 鍛造用被膜・潤 滑剤の評価方法としては室温 (Rt) から高温まで広く用い られている.摩擦係数を絶対值として求めることができる ため, 油性潤滑剂の摩擦係数を低減させる効果などの評価 には利用可能と考えられる. 最近では, リング圧縮試験法 を用いて塩素を含まない潤滑油など無害な潤滑油の開発 のために, 極微量の潤滑油を噴霧するセミドライ加工 ${ }^{8)}$ で の摩擦状態が測定されている.

Table 1. Frictional condition for metalworking.

\begin{tabular}{|c|c|c|c|c|}
\hline $\begin{array}{ll}\text { Parameter } & \text { Forming } \\
\end{array}$ & $\begin{array}{l}\text { Sheet metal } \\
\text { forming }\end{array}$ & $\begin{array}{l}\text { Drawing, } \\
\text { Ironing }\end{array}$ & $\begin{array}{c}\text { Rolling, } \\
\text { Rotary forging }\end{array}$ & $\begin{array}{l}\text { Forging, } \\
\text { Extrusion }\end{array}$ \\
\hline Normal pressure ratio $\mathrm{P} / \mathrm{Y}^{*}$ & $0.1 \sim 1$ & $1 \sim 3$ & $1 \sim 3$ & $2 \sim 5$ \\
\hline Normal pressure (MPa) & $1 \sim 100$ & $100 \sim 1000$ & $100 \sim 1000$ & $100 \sim 3000$ \\
\hline Velocity $\mathrm{V} / \mathrm{m} \cdot \mathrm{s}^{-1}$ & $0 \sim 10^{-1}$ & $10^{-2} \sim 10^{2}$ & $10^{-2} \sim 10^{2}$ & $10^{-3} \sim 10^{-1}$ \\
\hline Relative sliding speed $\mathrm{v} / \mathrm{mm} \cdot \mathrm{s}^{-1}$ & $0 \sim 10^{-2}$ & $10^{-2} \sim 10^{0}$ & $10^{-2} \sim 10^{0}$ & $0 \sim 10^{-1}$ \\
\hline $\begin{array}{l}\text { Temperature of frictional } \\
\text { interface } \mathrm{T} /{ }^{\circ} \mathrm{C}\end{array}$ & $\mathrm{Rt} \sim 150$ & $\mathrm{Rt} \sim 300$ & $\begin{array}{l}\text { Rt } \sim 150 \text { Warm, } \\
\text { Hot working }\end{array}$ & $\begin{array}{l}\text { Rt } \sim 400 \text { Warm, } \\
\text { Hot working }\end{array}$ \\
\hline Surface expansion ratio $\mathrm{A} / \mathrm{A}_{0}{ }^{* *}$ & $0.5 \sim 1.5$ & $1 \sim 2$ & $1 \sim 2$ & $1 \sim 100$ \\
\hline $\begin{array}{l}\text { Supplying condition of lubricants } \\
\text { to frictional interface }\end{array}$ & Trapping & Infusion & Infusion & $\begin{array}{l}\text { Trapping } \\
\text { Infusion }\end{array}$ \\
\hline
\end{tabular}

${ }^{*} Y$ : Tensile strength of work ${ }^{* \star} A / A_{0}$ : Surface expansion ratio of work

Table 2. Various kind of Tribo-simulator for forging.

\begin{tabular}{|c|c|c|c|c|c|c|c|c|c|c|}
\hline \multirow[b]{2}{*}{ Testing method } & \multirow[b]{2}{*}{$\begin{array}{l}\text { Deformation } \\
\text { type }\end{array}$} & \multicolumn{3}{|c|}{ Deformation condition } & \multicolumn{4}{|c|}{ Obtainable information } & \multicolumn{2}{|c|}{ Change parameter } \\
\hline & & $\begin{array}{c}\text { Normal } \\
\text { pressure } \\
\text { ratio } \mathrm{P} / \mathrm{Y}^{*}\end{array}$ & $\begin{array}{c}\text { Relative } \\
\text { sliding speed } \\
\mathrm{v} / \mathrm{mm} \cdot \mathrm{s}^{-1}\end{array}$ & $\begin{array}{c}\text { Surface } \\
\text { expansion } \\
\text { ratio } A / A_{0}{ }^{* *}\end{array}$ & Tool wear & $\begin{array}{l}\text { Ejection } \\
\text { load }\end{array}$ & $\begin{array}{l}\text { Friction } \\
\text { coefficient }\end{array}$ & $\begin{array}{c}\text { Contact } \\
\text { thermal } \\
\text { conductance }\end{array}$ & $\begin{array}{c}\text { Work } \\
\text { temperature }\end{array}$ & $\begin{array}{c}\text { Tool } \\
\text { temperature }\end{array}$ \\
\hline Ring Compression Test & Upsetting & $2 \sim 3$ & $\sim 50$ & $1 \sim 3$ & $x$ & $x$ & 0 & 0 & 0 & 0 \\
\hline Backward Extrusion Test & Extrusion & $2 \sim 5$ & $\sim 300$ & $5 \sim 20$ & $x$ & $\bigcirc$ & $\triangle$ & $\triangle$ & $\bigcirc$ & $\bigcirc$ \\
\hline $\begin{array}{l}\text { Forward-Backward } \\
\text { Extrusion Test }\end{array}$ & Extrusion & $2 \sim 5$ & $\sim 300$ & $5 \sim 20$ & $x$ & $\bigcirc$ & $\bigcirc$ & $\triangle$ & $\bigcirc$ & $\bigcirc$ \\
\hline Injection Upsetting & Extrusion / Die forging & - & - & $5 \sim 12$ & $x$ & $x$ & O & $x$ & $\bigcirc$ & $\triangle$ \\
\hline Spike Forging Test & Extrusion / Die forging & $2 \sim 3$ & $\sim 130$ & $5 \sim 13$ & $\triangle$ & $\bigcirc$ & $\triangle$ & $\triangle$ & 0 & $\bigcirc$ \\
\hline Taper Cup Test & Extrusion & $2 \sim 3$ & & $5 \sim 40$ & $x$ & 0 & 0 & $\triangle$ & 0 & $\bigcirc$ \\
\hline Ball Penetration Test & Ironing / Varnishing & $2 \sim 3$ & $\sim 50$ & $1 \sim 2$ & $x$ & $x$ & 0 & $\triangle$ & 0 & $\triangle$ \\
\hline $\begin{array}{l}\text { Intermittent Sliding } \\
\text { Friction Test for Forging }\end{array}$ & Upsetting / Die forging & $2 \sim 3$ & $\sim 200$ & $1 \sim 2$ & $\bigcirc$ & $x$ & $\bigcirc$ & $\bigcirc$ & $\bigcirc$ & $\triangle$ \\
\hline $\begin{array}{l}\text { Tribo-tester on localized } \\
\text { rod-drawing method }\end{array}$ & Drawing / Ironing & $2 \sim 5$ & $\sim 100$ & $1 \sim 7$ & $x$ & $x$ & $\bigcirc$ & $x$ & $\bigcirc$ & $\bigcirc$ \\
\hline Flange Header Test & $\begin{array}{l}\text { Upsetting / Die } \\
\text { forging }\end{array}$ & $2 \sim 3$ & $\sim 130$ & $1 \sim 15$ & $\triangle$ & $x$ & $\Delta$ & $x$ & $\bigcirc$ & $\Delta$ \\
\hline
\end{tabular}

${ }^{*} \mathrm{Y}$ : Tensle strength of work ${ }^{* \star} \mathrm{A} / \mathrm{A}_{0}$ : Surface expansion ratio of work

$\bigcirc$ : Easy,possible $\triangle$ : Possible $X$ : Impossible 
2 章で示した, 後方押出し法の一つとして, 後方穿孔加 工法は，パンチの成形 $\mathrm{R}$ 部やランド部の長さを種々に変 えることにより焼付きに対する敏感性を変化させ, 実験法 3)としたものである。この試験法は, 実用試験法として潤 滑剂や型材の潤滑特性評価が行われており, 成形後のパン チの引抜き力による評価のほかに被加工材の表面近傍の 材料流れやパンチ表面の残留応力を測定するなど,一つの 評価 ${ }^{9)}$ 試験から得られる情報だけでなく多角的にトライ ボ特性をとらえようと試みられている。しかし，パンチの $\mathrm{R}$ 部での急激な塑性変形は, トライボ特性評価值として摩 擦抵抗に大きな影響を及ぼす面圧と大きな表面積拡大比 の安定的な観察が難しく, 実験データの定量化を困難にし ている.

その点を解決するための実用的な評価試験法として, テーパカップ試験法 ${ }^{5)}$ が提案されている. 本手法は, 後 方押出し時のパンチの成形 $\mathrm{R}$ 部での急激な表面積拡大の 変化を避けるために, テーパ状のパンチを用いて押出しを することにより，Fig.5 に示したようにテーパパンチ面に 渡り大きな表面積拡大を確保できる。 そのため, 安定した 被膜の評価が可能となった. Fig.6 は，テーパカップ試験 による化成被膜 (Lub.A), 一液潤滑液（Lub.B.C）および油 性潤滑油 (Lub.D) の評価結果を示している。一定の押込み 深さや, 加工度（表面積拡大比）を確保する際にいかに低 荷重で成形を行うかが被膜・潤滑油の種類により判定でき る.また, Fig.7に, 種々の硬質皮膜処理をほどこしたテー パパンチを用いた連続鍛造時のせん断摩擦係数の変化を 示す. 使用中の摩擦係数が下がる理由は, 加工により表面 粗さが低下するためであり, $\mathrm{TiC}$ のような硬い被膜より TiNのような軟らかい硬質皮膜のほうが摩擦係数の低下速 度が顕著である。このように，テーパカップ試験により実

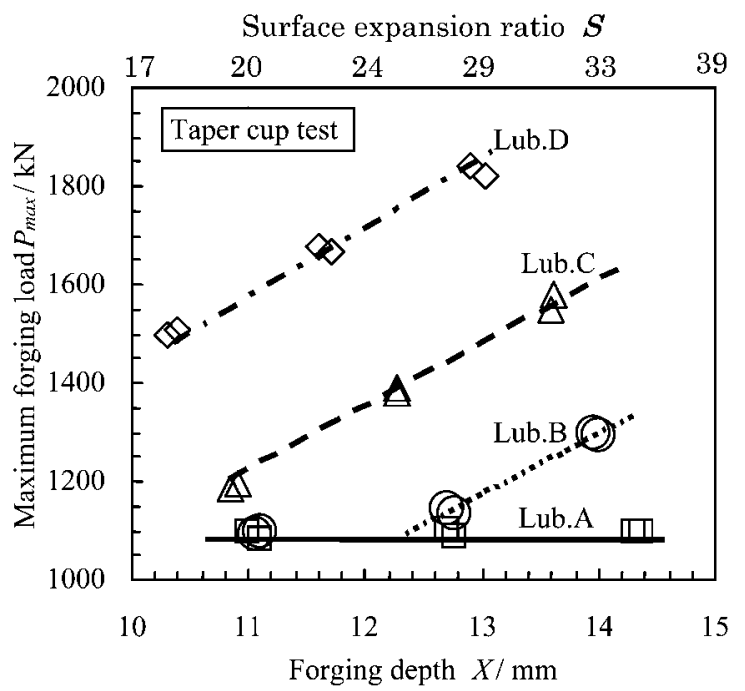

Fig.6. Relationship between forging depth and forging load in Taper Cup Test.

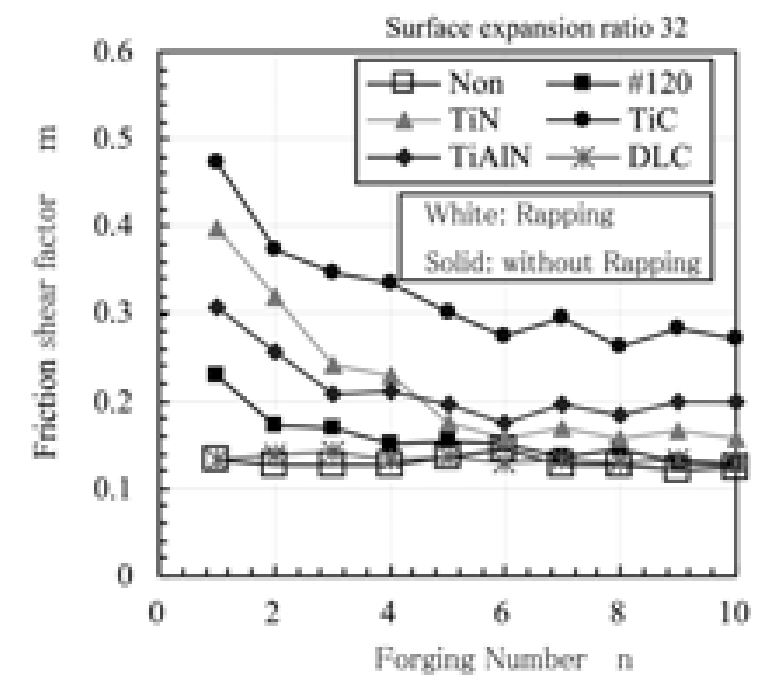

Fig.7. Change of friction shear factor in the sequence of Taper Cup Test.

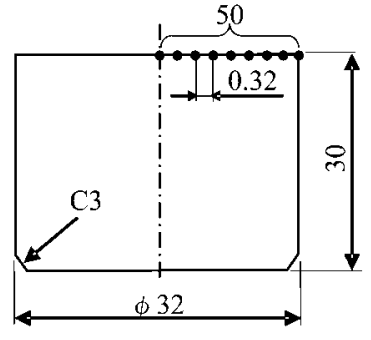

(a) Schematic illustration of work piece before and after deformation

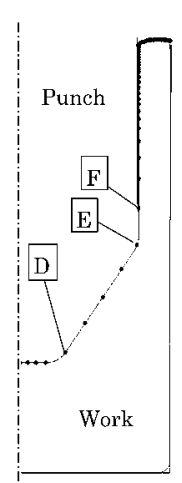

Fig.5. Relationship between normal pressure and surface expansion ratio in Taper Cup Test.

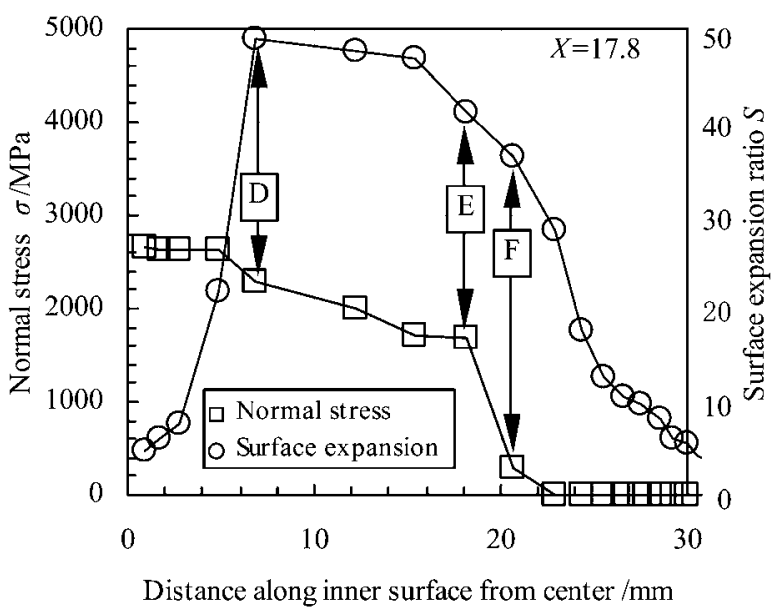

(b) Distribution of surface expansion ratio 
加工における成形状態の変化が直接計測できる.

後方押出しにおける摩擦係数の測定を可能とするため に, 複合押出し形鍛造用摩擦試験法による潤滑性能の比較 評価法が開発されている。この中で，Fig.8 に示すような 後方穿孔押出し形摩擦試験法 (前 · 後方缶押出し法) 10),11) が提案されている. 基本的な变形機構は, 先にのべた後方 押出し法と同じであるが, 上パンチと下パンチのベアリン グ部長さを変えることにより摩擦抵抗に及ぼす材料流動 の変化から穿孔荷重のバランスを数值計算にてあらかじ め求めておき, 大きな表面積拡大比の場合でも摩擦係数が
絶対值として求められることに特徵がある. 本試験方法を 用いて, A6061 材に対する化成被膜と耐焼き付性の関係が 求められている.

後方押出し試験は実用試験であるが, これに近いトライ ボ状況で簡易な試験法として Fig.9に示すスパイクテスト が提案 ${ }^{12)}$ されている。この試験法の特徴は, 円柱状試験 片の端面に塗布された被膜の特性を，ロート形状の金型に 前方押出しする時の摩擦抵抗と側方への摩擦抵抗とがバ ランスする時の成形荷重の大・小と押出し長さ（スパイク 高さ H）で評価することである。ここでは，押达み時の工

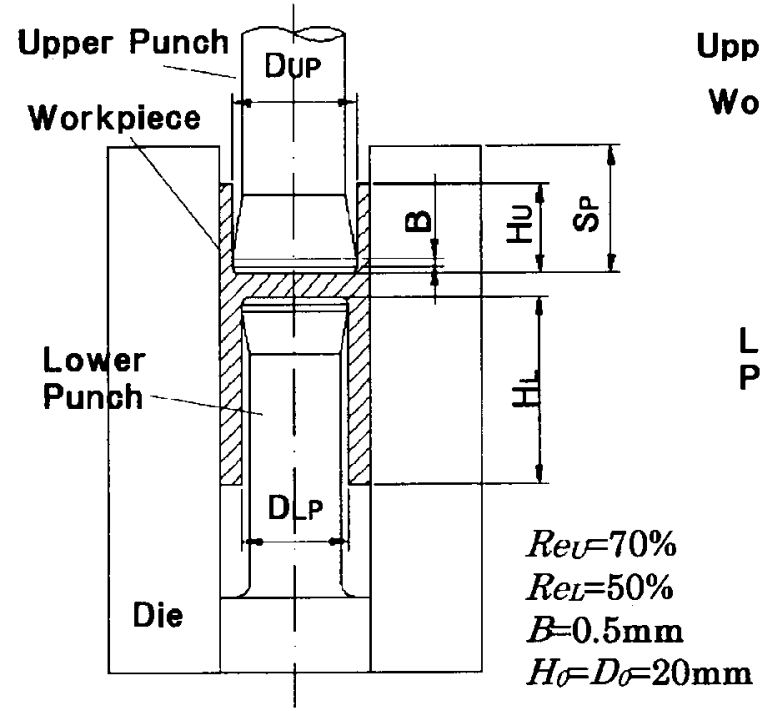

(a) For friction shear factor $m_{d}$ on die

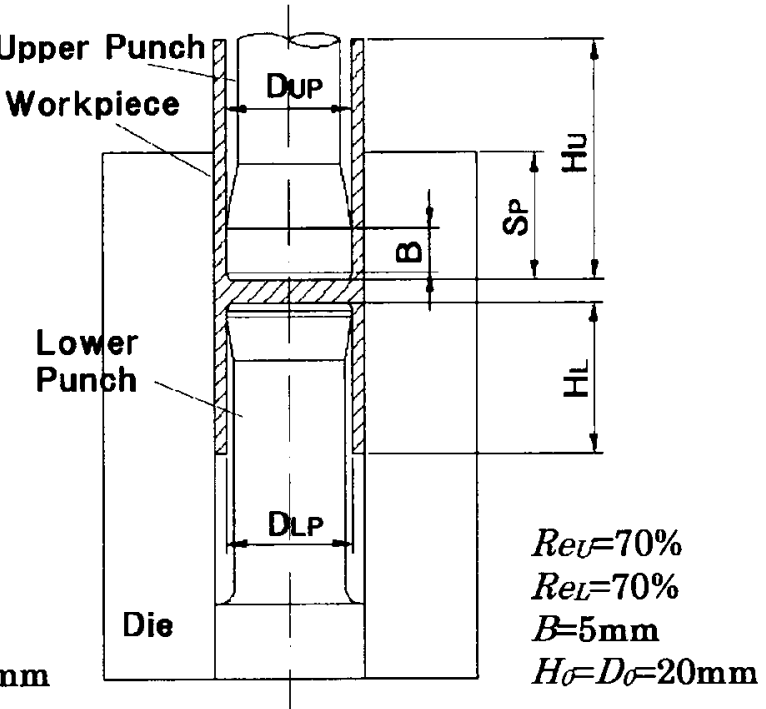

(b) For friction shear factor $m_{u p}$ on punch

Fig.8. Design of tribo-testing method based on forward-backward can extrusion.

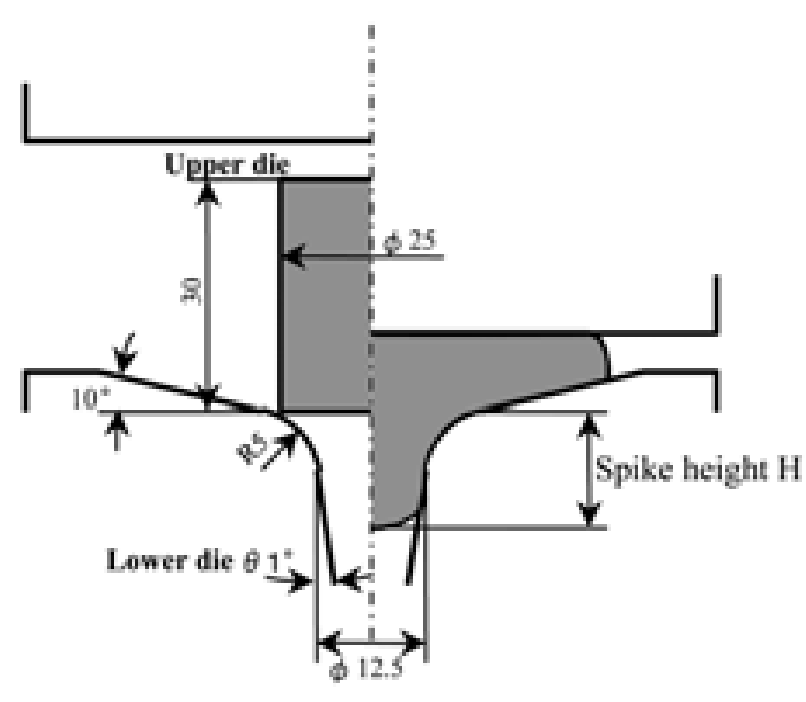

(a) Schematic illustration of Spike Forging Test

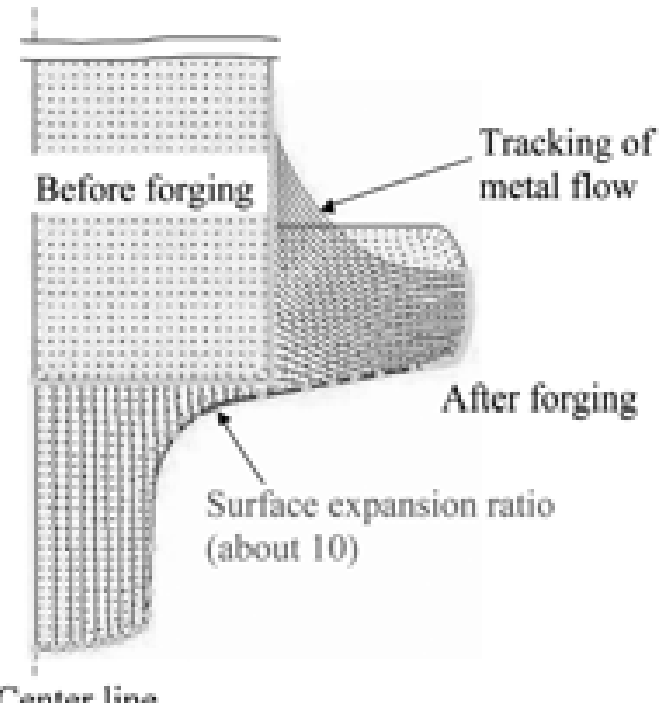

Center line

Fig.9. Spike Forging Test. 
具端面の摩擦抵抗を絶えず一定に制御するために, 上工具 端面には同心円の溝が施され, 固着摩擦状態により据込み パンチの摩擦エネルギーを常に一定としている. 押込み深 さの制御（Die Gap X) により表面積拡大比を 10 以上にす ることが可能で, 観察したい場所のみの摩擦抵抗を評価で きる点にある.Fig.1013)に，押达み量 Xを変えた時のせん 断摩擦係数 $\mathrm{m}$ とスパイク高さ $\mathrm{H}$ と成形荷重 Fs の関係を数 值計算により求めた特性曲線図上に示す.摩擦抵抗が小さ い時には，スパイク高さ $\mathrm{H}$ として表される前方押出し長

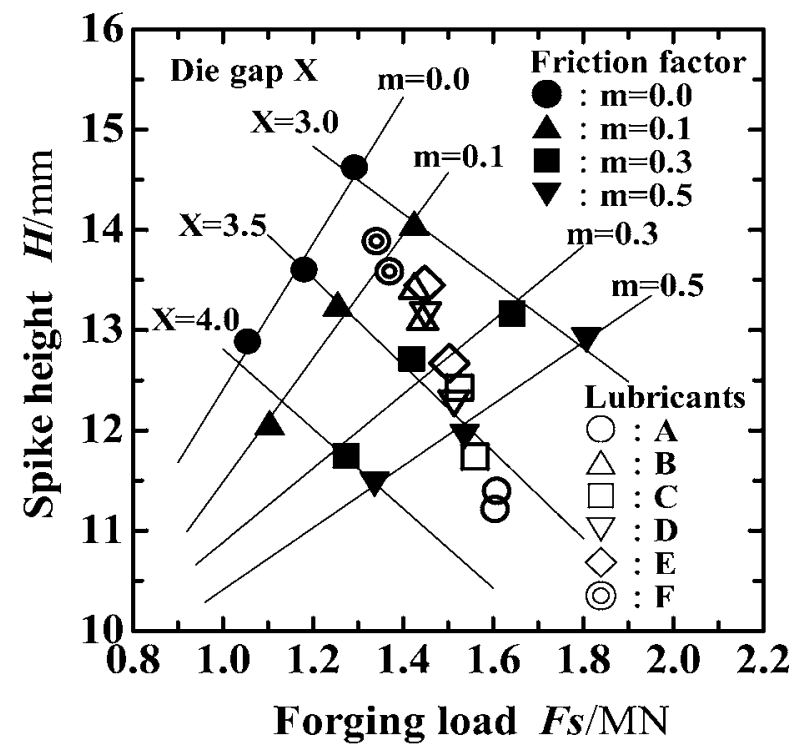

Fig.10. Experimental data of Spike Forging Test on the characteristic curve at $400{ }^{\circ} \mathrm{C}$.
さが長くなり, 成形荷重 Fs が小さくなる，種々の被膜 $\mathrm{A}$ 〜 F を評価すると, 特性曲線図上でその性能の序列が評価 できる.また，押込み後の試験片を取り出すときのエジェ クト荷重より連続成形の可能性も評価可能である. 本試験 法を用いて, 環境負荷を軽減する冷間鍛造用油性潤滑剂が 開発 ${ }^{14)}$ されている.

評価項目として焼付き限界の推定がある。これに対して は Fig.11に示すボール通し試験 ${ }^{15)}$ がもっとも簡易に行わ れる.ボール径と試験片の内径を変化させることによって 加工度を変え, その時のボール押込み力の変動や試験片内 面の観察, 材料流動の違いなどから総合的に焼付き防止能 を評価できる. Fig.12 に市販潤滑剤を評価した一例を示 す. 押込み深さ S が大きいほど耐焼付性能は高いと判断さ れる.この場合, 化成処理膜の焼付き防止能が高く, 極圧 添加剂や粘度の効果が示され, この試験法を用いて冷間鍛 造用油剂が開発 16) された。しごき変形であり表面積拡大 比があまり大きくとれないなどの問題はある.

引き抜いた線材表面に強固な被膜を形成した状態での トライボ特性を評価する方法として, 通常の引抜き法では 表面積拡大比も接触面圧も大きくとれないが, Fig.13 に示 す局所引抜き型トライボ試験法 ${ }^{17)}$ では, ダイスの面を平 面から各種歯形形状に変更することで表面積の拡大比を 局所的に 7 程度まで可能としている．Fig.4 に示したよう に，歯だし鍛造時の表面積拡大比はせいぜい 10 以下であ り, 面圧の大きさがポイントとなる. Fig.13-(b) に示す種々 の歯形を用いて引抜きを行うと, Fig.14に示すような歯形

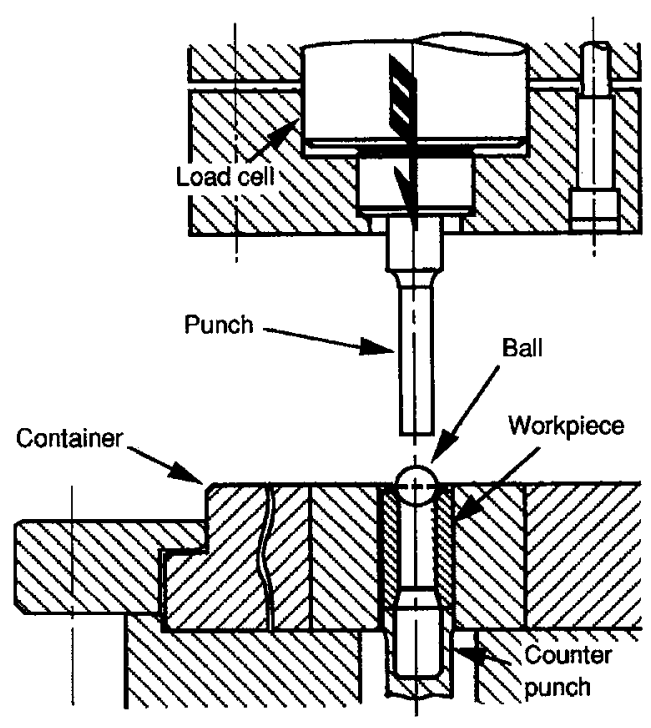

(a) Schematic arrangement of the Ball Penetration test

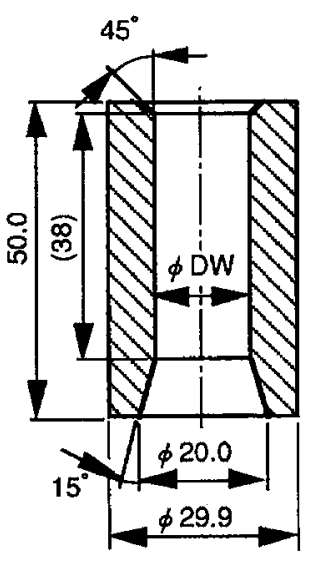

\begin{tabular}{c|c|c}
\hline $\mathrm{R}^{*} / \%$ & $\mathrm{DB}^{* *} / \mathrm{mm}$ & $\mathrm{DW}^{* * *} / \mathrm{mm}$ \\
\hline 4 & 15.88 & 15 \\
6 & 15.88 & 14.5 \\
8 & 16.67 & 15 \\
10 & 16.67 & 14.5 \\
12 & 17.46 & 15 \\
14 & 17.46 & 14.5 \\
\hline
\end{tabular}

${ }^{*} \mathrm{R}$ : Reduction in cross-sectional area ** DB: Ball diameter

*** DW: Inside diameter of workpiece $R=\frac{D B^{2}-D W^{2}}{30^{2}-D W^{2}} \times 100 \%$

(b) Geometry or work piece and relationship between R,DB and DW

Fig.11. Design of tribo-testing method based on Ball Penetration Test. 


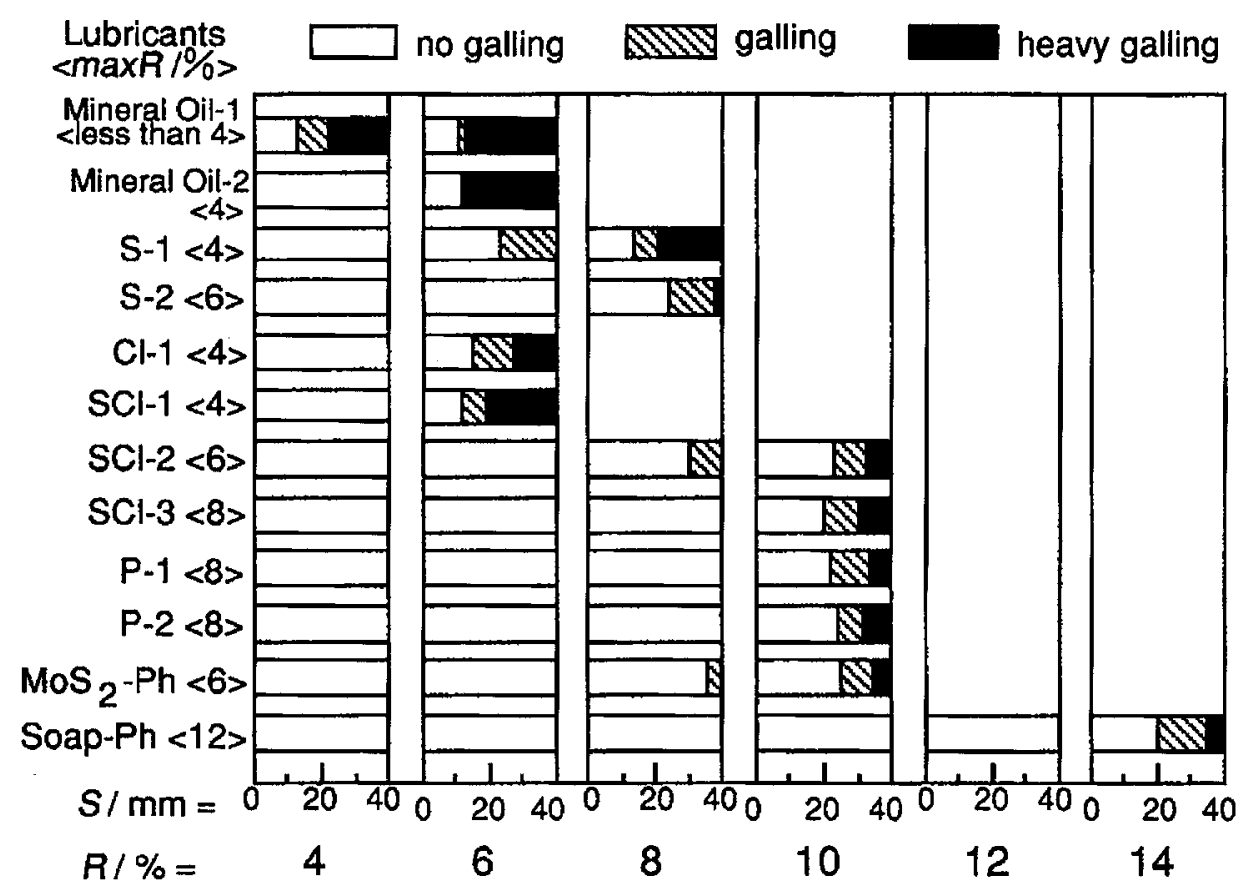

Fig.12. Reduction of cross-section area $\mathrm{R}$ and distance from top end of work piece $\mathrm{S}$ where galling occur.

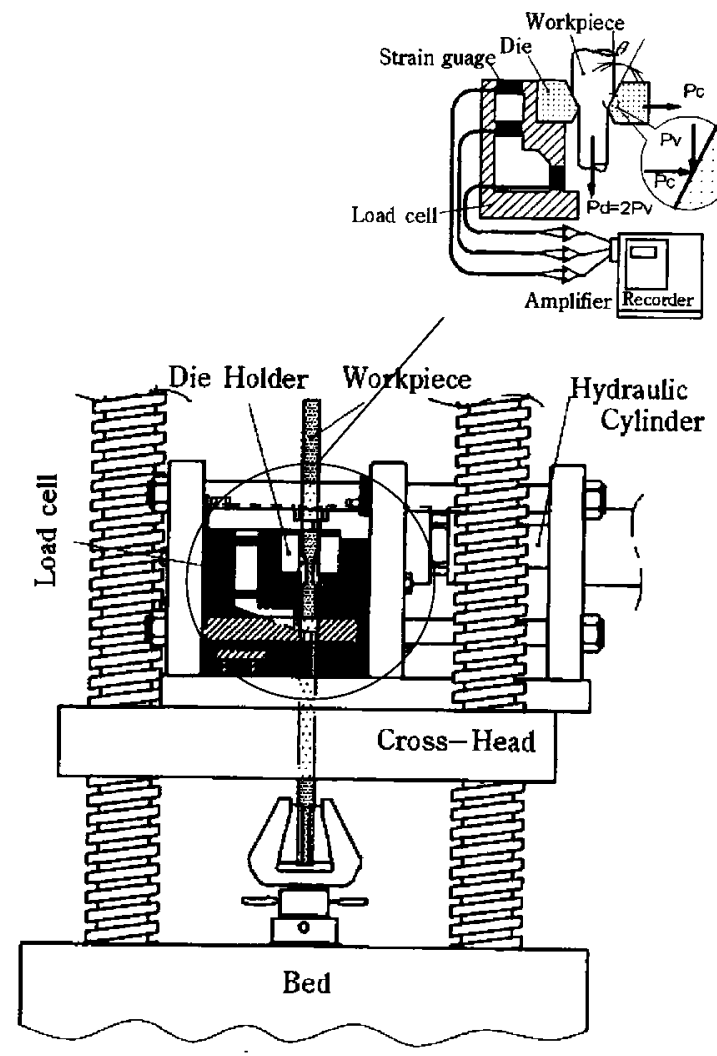

(a) Die set-up

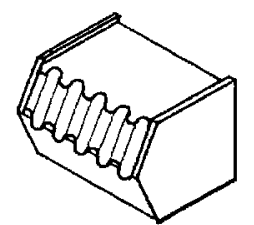

Isometric view

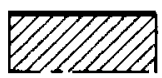

(a) Flat Surface
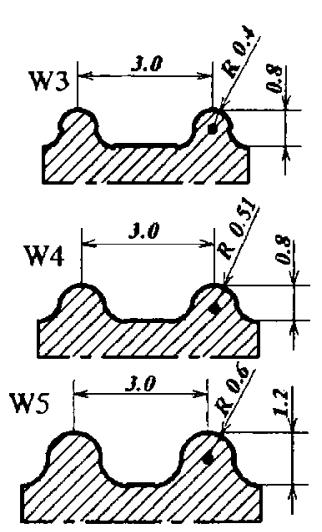

(c) Multi-Surface

(b) Detail of die geometry

Fig.13. Experimental set-up and Die geometry in Localized rod drawing simulation. 


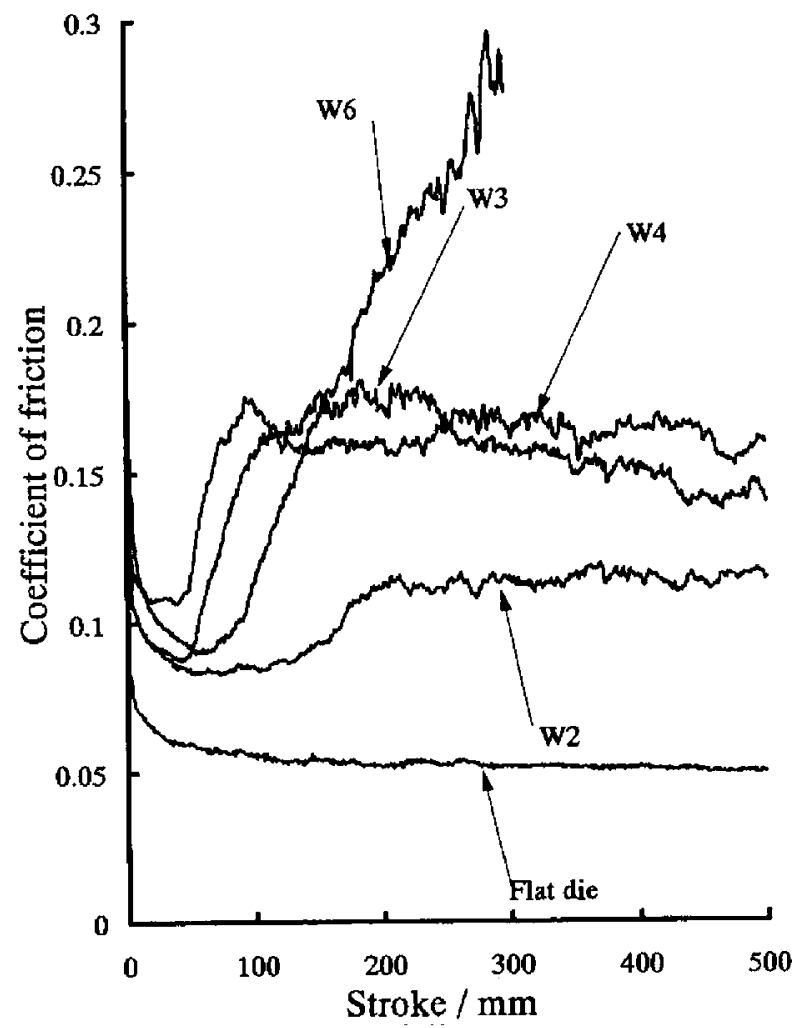

Fig.14. Influence of die geometry on interface friction.

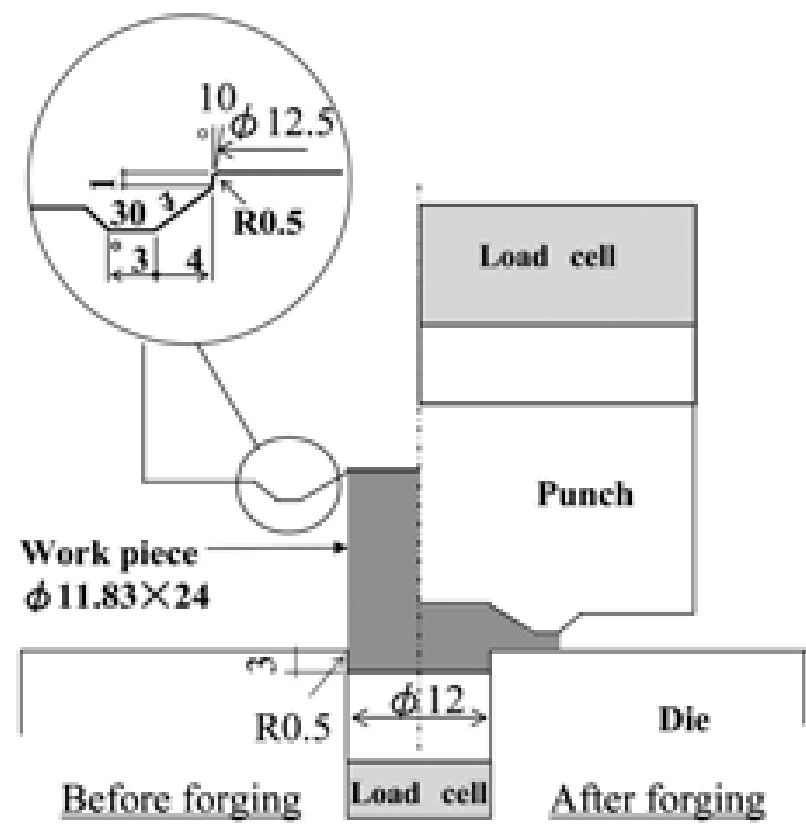

(a) Illustration of Flange Header Test
Fig.15 に示すフランジヘッダー試験法 ${ }^{18)}$ は，線材を用 いてボルトなどを製造するプロセスにおいて, ボルト座面 の焼付きを評価するのに適している.後方押出し時ほどの 表面積拡大比は生じないが, メタルフローが直角に曲げら れ局部的な面圧が大きくなる場合などに適用される．特 に, 量産されている線材から直接割愛した試験片を用いた 試験が可能であり，より実用的な試験法である。

\section{4. まとめ}

環境問題に対する認識が高まり, 環境污染をもたらす加 工用被膜・潤滑剂の使用が厳しく制限されるようになっ た.このような状況で, 鍛造加工の特徵である, 高面圧, 大きな表面積拡大比, そして接触界面の高い温度を摩擦界 面で直接安定して繰返し計測できるトライボロジーシ ミュレータがあれば, 環境に易しい被膜・潤滑剤の開発は 大きく前進すると思われる.

現実には実鍛造加工時のトライボ状況をすべて再現可 能な試験法は見あたらないので, それぞれの変形様式にあ わせた試験法を選択し評価が進められている。しかし，そ れぞれの試験から得られた結果が同一のデータベースと して構築され, 統一して解釈されることは極めて困難であ る.

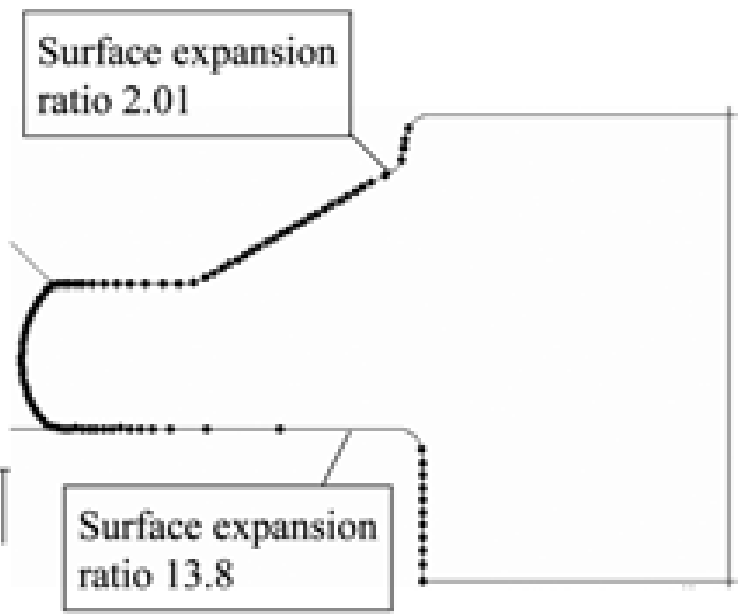

(b) Surface expansion ratio after forging

Fig.15. Flange Header Test. 
また, 被膜・潤滑剂の違いによるミクロなトライボ条件 の変化は, 被加工材の表面および内部のひずみに微妙な影 響を与え,たとえば歯車などのように加工後に浸炭熱処理 を施す場合, その結果熱処理後の変形ひずみの差異などを もたらす可能性もある.マクロな加工条件を正確に再現で きるとともに, 加工限界も含め数值計算上でミクロなトラ イボ条件まで含めた検証を可能にするためには実体加工 条件を確実に再現できる評価試験法の出現に対する期待 が強い.

(文 献)

1）日本塑性加工学会編:塑性加工におけるトライボロ ジー,コロナ社, 1988, 67.

2) Male,A.T. and Cockcroft,M.G.: J. of the Inst. of Metals, 93 (1964), 38.

3) 水野高爾, 小島之夫, 北村憲彦, 朱偉成:塑性と加工, 25 (1984), 929.

4）日本塑性加工学会編:塑性加工におけるトライボロジー, コロナ社, 1988, 71.

5) 伊藤樹一, 吉田広明, 五十川幸宏, 土井善久, 堂田邦明: 塑性と加工, 48 (2007), 303.

6）日本塑性加工学会編:塑性加工におけるトライボロジー, コロナ社, 1988, 65.

7) 土井善久,伊藤樹一, 吉田広明, 五十川幸宏: 塑性加工連 合講演会論文集, 56 (2005), 611 .

8）松本良, 小坂田宏造:塑性と加工, 44(2003),535.

9) 野々山史男, 北村憲彦, 渡辺三千雄, 団野敦: 塑性と加工, $34(1993), 1166$.

10) T. Nakamura, S. Tanaka, K. Hayakawa and I. Takahashi: Tribo-Testing method for Estimating Tribo-Characteristics at Piercing Punch in Backward Can Extrusion, Lubricating Engineering, 59 (2003), 4, 12.

11）熟坂芳宏, 中村保, 田中繁一, 早川邦夫: 塑性と加工, 48 (2007), 56.

12) S.Isogawa, A.Kimura, and Y. Tozawa:CIRP Ann., 42 (1992), 1, 263.

13) S.Isogawa and Y.Tozawa:Evaluation of Additives in Cold Forging Oil by Spike Forging Test, $30^{\text {th }}$ ICFG Meeting, (1997).

14）深谷輝雄, 吉田広明, 伊藤樹一, 五十川幸宏: 塑性加工 連合講演会論文集, 56 (2005), 615 .

15）北村憲彦, 大森俊英, 団野敦, 川村益彦: 塑性と加工, 34
(1993), 1178.

16）北村憲彦, 大森俊英:塑性と加工, 39 (1998), 452.

17) H. Saiki, N.Gracious and R. Liqun, J. of Mat. Proc. Tech., 63 (1997), 238.

18）伊藤樹一, 吉田広明, 五十川幸宏, 堂田邦明: 塑性加工 連合講演会論文集, 56 (2005), 613 . 